\title{
Antimicrobial stewardship strategies in wound care: evidence to support the use of dialkylcarbamoyl chloride (DACC)- coated wound dressings
}

Mark G Rippon,1 PhD, Visiting Clinical Research Associate*; Alan A Rogers,2 BSc, Independent Wound Care Consultant; Karen Ousey,2,3,4 PhD

Professor of Skin Integrity, Director for the Institute of Skin Integrity and Infection Prevention; Adjunct Professor; Visiting Professor *Corresponding author email: markgeoffreyrippon@gmail.com 1 Huddersfield University, UK. 2 WoundCareSol Consultancy, UK. 3 School of Nursing, Faculty of Health at the Queensland University of Technology, Australia. 4 Royal College of Surgeons in Ireland, Dublin, Ireland.

Journal of Wound Care 30(4): 284-296 (2021) 
Abstract

Background: Traditionally, infections are treated with antimicrobials (for example, antibiotics, antiseptics, etc), but antimicrobial resistance (AMR) has become one of the most serious health threats of the $21^{\text {st }}$ century (before the emergence of COVID-19). Wounds can be a source of infection by allowing unconstrained entry of microorganisms into the body, including antimicrobial-resistant bacteria. The development of new antimicrobials (particularly antibiotics) is not keeping pace with the evolution of resistant microorganisms and novel ways of addressing this problem are urgently required. One such initiative has been the development of antimicrobial stewardship (AMS) programmes, which educate healthcare workers, and control the prescribing and targeting of antimicrobials to reduce the likelihood of AMR. Of great importance has been the European Wound Management Association (EWMA) in supporting AMS by providing practical recommendations for optimising antimicrobial therapy for the treatment of wound infection. The use of wound dressings that use a physical sequestration and retention approach rather than antimicrobial agents to reduce bacterial burden offers a novel approach that supports AMS. Bacterial-binding by dressings and their physical removal, rather than active killing, minimises their damage and hence prevents the release of damaging endotoxins.

Aim: Our objective is to highlight AMS for the promotion of the judicious use of antimicrobials and to investigate how dialkylcarbamoyl chloride (DACC)-coated dressings can support AMS goals.

Method: MEDLINE, Cochrane Database of Systematic Reviews, and Google Scholar were searched to identify published articles describing data relating to AMS, and the use of a variety of wound dressings in the prevention and/or treatment of wound infections. The evidence supporting alternative wound dressings that can reduce bioburden and prevent and/or treat wound infection in a manner that does not kill or damage the microorganisms (for example, by actively binding and removing intact microorganisms from wounds) were then narratively reviewed.

Results: The evidence reviewed here demonstrates that using bacterial-binding wound dressings that act in a physical manner (for example, DACC-coated dressings) as an alternative approach to preventing and/or treating infection in both acute and hard-to-heal wounds does not exacerbate AMR and supports AMS.

Conclusion: Some wound dressings work via a mechanism that promotes the binding and physical uptake, sequestration and removal of intact microorganisms from the wound bed (for example, a wound dressing that uses DACC technology to successfully prevent/reduce infection). They provide a valuable tool that aligns with the requirements of AMS (for example, reducing the use of 
antimicrobials in wound treatment regimens) by effectively reducing wound bioburden without inducing/selecting for resistant bacteria.

Declaration of interest: This study was funded by an Educational Grant from ABIGO Medical AB, Sweden. The authors have no other conflicts of interest to declare. 
An increasing number of microorganisms are acquiring antimicrobial resistance (AMR) to agents (for example, antibiotics) that are used to fight them. important challenge to clinical and 1 This is a budgetary resources worldwide. 2 The problem is exacerbated by the fact that development of new antibiotics is slow and in decline, and is being outpaced by the increasing resistance of these microorganisms; therefore, new strategies to tackle this problem are needed.3-5 Progress has been made using strong infection control and targeted use of antibiotics, leading to a reduction in infections of antibiotic-resistant microorganisms.6 Antimicrobial stewardship (AMS) programmes have provided a systematic effort to inform, educate and persuade prescribers of antimicrobials to follow evidencebased prescribing to stem antibiotic overuse and help reduce AMR.2 Nevertheless, because of AMR, and in addition to AMS programmes, new methods of treating resistant bacteria are urgently required, particularly in wound care. This has been highlighted by the European Wound Management Association (EWMA) as being a key challenge for clinicians working in the wound care field.7,8 It has also been underlined by initiatives with which EWMA are currently involved, such as AMS podcasts, 9 and establishing partnerships with organisations and groups that have mutual and synergistic objectives on the AMR agenda (such as the British Society for Antimicrobial Chemotherapy).7

This article presents the case (by providing laboratory and clinical evidence) for using wound dressings that provide a physical mechanism of antimicrobial action to effectively prevent and/or treat wound infections, while supporting the AMS premise of reducing antibiotic usage.

\section{Methods}

Medline, Cochrane Database of Systematic Reviews, and Google Scholar were searched for relevant articles regarding the use of wound dressings and AMS in wound care, published between January 1970 and November 2020. The following keyword search strategy was used: 'antimicrobial stewardship', 'wound AND dressing', 'ulcer' and 'antibiotic resistance'. In addition, the authors also conducted a manual search of relevant wound care journals not cited in Medline/PubMed (for example., Wounds UK and Wounds International).

Data from both randomised and non-randomised clinical trials, clinical cohort studies and case series reports written in English were included. In vitro studies, case reports, case series and articles not written in English were excluded. This article was not intended to be a systematic review or metaanalysis but as a 'narrative overview'.10

\section{Wound infection treatments}

Antimicrobial agents 
An important aspect of wound management is the use of antimicrobial agents to treat wound infection, which is one of the most frequent complications of wounds, particularly hard-to-heal wounds.11 In the worst cases, wound infection can lead to life-threatening conditions.12 Fig 1 illustrates a hard-to-heal wound infected by Pseudomonas aeruginosa.

There is a myriad of strategies for the treatment of wound infection in wound care. Traditional antimicrobials (for example, antibiotics and antiseptics) directly reduce bioburden by inhibiting the growth/bacterial cell division of wound microorganisms13 and/or killing them to provide bioburden control. Novel approaches aid the physical removal of intact microorganisms from wounds (for example, the binding to and removal of microorganisms by DACC-coated wound dressings) rather than actively killing bacteria, providing a physical mechanism for the control of bioburden.14,15

Antimicrobials used in wound care can be divided into several broad categories including antibiotics, biocides and anti-infective biologics (Fig 2). The risk of developing AMR has led to the recommendation that topical antibiotics should not be used for the treatment of hard-to-heal wounds.11 Non-antibiotic antimicrobials widely used in wound care include antiseptics, such as chlorhexidine,16 povidone or cadexomer iodine,17,18 polyhexamethylene biguanide (PHMB),19 metals (for example, silver)20 and natural products (for example, honey).21,22 As with the use of antibiotics, the widespread use of lowconcentration antiseptics has raised concerns about the possibility of the emergence of antiseptic resistance, 23 although there has been little discussion of antiseptic resistance in treatment guidelines. 24

In topical form, antimicrobials may be helpful where there is localised (surface) infection of hard-toheal wounds,11 although some topical antimicrobials (for example, antiseptics) may delay wound healing,11,25,26 cause periwound skin irritation,11 and have potential cytotoxic effects in the wound bed, especially with long-term treatment.25,27 This negative aspect of antimicrobial treatment has led to debate surrounding the use of topical antimicrobials in wound treatment, with reports of in vitro cytotoxicity with chlorhexidine 28 and povidone-iodine,29,30 and adverse clinical reactions.31

Antimicrobial dressings

The development of new drugs and target opportunities (i.e., bacterial binding and removal rather than active killing) is a fundamental requirement in the battle against AMR. Antimicrobial dressings are an example of limiting exposure of antimicrobials to local sites of infection and are an important tool in current antimicrobial therapy: the use of combinations of antibiofilm/antimicrobial agents has been shown to manage infection and biofilm, and to facilitate healing progression. 32 
In terms of selective targeting of bacteria, several antimicrobial agents have been incorporated into different dressing types.33 Common antiseptics, such as silver, iodine and PHMB can provide effective antibacterial action across a broad range of wound pathogens and there is an increasing body of in vitro evidence in support of their use.2,8,34

In contrast, there are wound dressings that do not contain active agents, but that act by binding bacteria to prevent/reduce wound infection. They do this by reducing the local bioburden of a wound via the physical uptake, sequestration and removal of microorganisms from the wound bed. There is a significant body of clinical evidence in support of dialkylcarbamoyl chloride (DACC)-coated dressings preventing and reducing infection in wounds via bacterial binding, 35 and it illustrates how these dressings, acting by physical means, can be used successfully to prevent/treat wound infections, and be aligned to support an AMS strategy.

DACC is a fatty acid derivative that is highly hydrophobic, and hydrophobicity plays a crucial role in the adherence of microorganisms to surfaces.36 The microorganisms commonly responsible for causing surgical site infections (SSIs) or for colonising hard-to-heal wounds generally have hydrophobic extracellular surfaces and will irreversibly adhere to the DACC coating on dressings.37 Several microorganisms important in wound infection have been shown to bind to DACC-coated material (Fig 3), including multidrug resistant microorganisms (MDROs) (for example, methicillin-resistant Staphylococcus aureus (MRSA)) and microorganisms present as part of biofilms.38 A range of studies exploring numerous wound types (for example, SSIs, hard-to-heal wounds, burns) have shown the effective use of DACC-coated dressings in the prevention and management of wound infection and in reducing wound bioburden (Table 1 and Table 2).

Once microorganisms are bound to the DACC-coated dressing (Fig 3) they can be removed from the wound.39 This reduces the bioburden of a wound and enhances wound healing: for example, clinical studies have shown elimination of the signs of infection in many patients with colonised or infected wounds when treated with DACC dressings (Table 2). In addition, Stanirowski et al.40 demonstrated that the use of bacterial-binding dressings following caesarean section has the potential to reduce the incidence of SSI and costs of treatment. The reduced microorganism load then helps to create optimal wound conditions for healing.39 As the mechanism of antimicrobial action with DACC is physical binding and removal, the lack of microorganism cell killing and disruption-as would happen with the action of antibiotics, other antimicrobial agents or antiseptics - prevents the release of endotoxin into the wound bed, minimising additional inflammatory stimulus.41

In a recent systematic review, Totty et al.35commented that, due to the physical nature of DACC's proposed mechanism of action, there is no risk of bacteria developing resistance. In addition, these 
dressings bind antibiotic-resistant microorganisms such as MRSA.38,42 Relying on a physical, bacterial-binding mode of antimicrobial action means that these dressings do not release any chemical or pharmacological antimicrobial agents, which may account for the lack of adverse effects to date for the use of DACC-coated dressings and suggests that these dressings may be used in all wound patient groups. 43

\section{Antimicrobial resistance}

Discussion on antimicrobial resistance tends to focus on antibiotic resistance. But, as with the use of antibiotics, the widespread use of biocides, such as antiseptics, particularly at low levels, has raised concerns about the possible emergence of antiseptic resistance in microbes, 23 a concern that must be acknowledged. However, the data regarding the mechanism of resistance and the involvement of antiseptic resistance in wounds are limited compared with antibiotic resistance. 24

Bacteria exposed to sub-lethal doses of antibiotics can mutate and resist antibiotic treatments via the natural selection of resistance-conferring genetic changes. 44 The widespread use of antibiotics in hospitals and the community setting, together with them being regarded as safe and effective, as well as inexpensive, has led to their misuse, through use without a prescription and overuse for self-limiting infections.45-47 There are few studies that have attempted to quantify the level of inappropriate antibiotic prescribing.48 Data on the prevalence of the inappropriate use of antimicrobials vary. A US study in 2007 stated that in hospitals, up to $50 \%$ of antimicrobial use was inappropriate.49 A more recent survey in 2016 suggested that an estimated $30 \%$ of outpatient, oral antibiotic prescriptions may have been inappropriate.50 Another study suggests that approximately $20 \%$ of antibiotics are inappropriately prescribed in UK primary care settings.48

The world is facing a rapidly worsening crisis related to the rise in the rates of resistance of bacterial pathogens to available therapeutic antimicrobial agents-even to many 'last resort' agents.7,51 AMR is a growing public health challenge worldwide that was identified as one of the top 10 threats to global health by the World Health Organization (WHO) in 2019.52 According to a recent analysis, between 2000 and 2015, global consumption of antibiotics increased by 65\%, from 21.1-34.8billion defined daily doses (DDDs), while the antibiotic consumption rate increased by $39 \%$, from 11.3-15.7 DDDs per 1000 individuals per day over the same period. If this trend continues unabated, global antibiotic consumption in 2030 is poised to be up to $200 \%$ greater than the 42 billion DDDs estimated for 2015.53

Over the last 30 years or so, AMR has been increasing, especially in healthcare environments, 51 while no new classes of antibiotics have been developed and there have been no new classes of antibiotics 
given regulatory approval since the late 1980s.7,54 Current antibiotics may become ineffective within 20 years.51 Largely due to inappropriate clinical use and misuse of antimicrobials, microorganisms have acquired-in a variety of ways - a resistance to drugs resulting in what has been termed an 'epidemic' of bacterial resistance.55,56 The inappropriate use of antibiotics represents the most important factor in the spread of drug-resistant microorganisms.57 At the current rate, it is estimated that AMR could kill an estimated 10 million people per year and cost in the region of \$100-200 trillion USD globally by 2050.58 Recent research has shown that 1-in-3 people will be given antibiotics in any one year and at least $20 \%$ of these prescriptions are inappropriate.59 In 2015, AMR was estimated to cause over 50,000 deaths annually in Europe and the US and was projected to reach 10 million by 2050.60 The cost to the US healthcare system alone for antibiotic-resistant infections is between \$21 billion and $\$ 34$ billion each year.61 According to the WHO, AMR could well be a global catastrophe within our lifetime, with many people becoming incapacitated or dying from simple infections that have become complicated.62

Resistant microorganisms identified to date span a spectrum of bacteria that are responsible for and exacerbate many diseases. The WHO has identified the priority pathogens that require new antibiotics (Table 3).

Antimicrobial resistance in wounds

Generally, the causes of the spread of MDROs are various but inappropriate use of antibiotics represents the most important factor.57 Direct consequences of infections with MDROs include longer duration of illness, increased mortality, prolonged length of hospital stay and increased costs.63,64 Antibiotics are frequently prescribed for patients with non-bacterial infections65 increasing antibiotic selection pressure and increasing MDROs.66 Treatments for wound infection that do not involve the use of antibiotics, antimicrobials or antiseptics are essential to promote AMS practices.67 Products that offer an alternative approach to the management of increasing bacterial load in hard-to-heal wounds, such as dressings with a physical mode of action, are effective in wound bioburden management as there is no risk of bacteria developing resistance.68,69 A recent Best Practice Statement on the wound management strategies for AMS indicates that, for infection management, dressings that do not contain an active/pharmaceutical component, and instead have a physical mode of action to reduce bacterial load, offer an ideal option in the drive to promote AMS practices.70

A wound is an injury involving any break in skin integrity. A rapid wound healing response is necessary to prevent blood loss and seal the wound from external contaminants, after which the healing process continues to re-establish normal tissue function.71 Acute wounds (for example, from surgery or 
trauma) heal via a series of sequential and overlapping steps; the inflammatory, proliferative and the remodelling phases.72,73 Hard-to-heal wounds neither heal properly nor progress through these sequential, healing response phases. 74

All open skin wounds are colonised by bacteria acquired from either the host (commensal microorganisms) or the external environment.75 Wounds generally provide a warm, moist and nutritive environment that promotes bacterial proliferation, and the level of bioburden varies according to the magnitude of bacterial presence in the wound.76 Wound microorganisms can also persist in hard-to-heal wounds as a biofilm-a complex, sessile community of microbes attached to the surface of a wound that is tolerant to treatment (including antibiotics) and the host defence.7779 Particularly in hard-to-heal wounds, such as ulcers, with their compounding influences (for example, the patient's underlying disease processes), the persistent presence of high levels of bacteria can contribute significantly to the chronic nature of these wounds.80-82

The bioburden, as well as the virulence of the organisms, the synergistic action of different bacterial species and the ability of the host to mount an immune response, determine the transition from contamination to colonisation to infection. 83,84 Infection cannot be predicted by the presence of a specific type of microorganism or by a quantity of bacteria85 and the host immune response plays a critical role in determining whether wound infection occurs. 86

Wound infection is a significant problem in both acute (surgical) wounds leading to SSIs and hard-toheal wounds:68

- SSIs occur in wounds created because of a surgical procedure and are one of the most important causes of healthcare-associated infections (HCAls). In a national SSI surveillance report for NHS hospitals in England (for the period April 2012 to March 2017), the cumulative 30-day SSI incidence rate was $1.26 \%$, ranging between $9.97 \%$ for large bowel surgery and $0.54 \%$ for knee prosthesis. 87 Due to the large number of surgical procedures conducted annually, the financial and social costs associated with SSIs can be considerable.88 A UK prevalence survey undertaken in 2006 suggested that approximately $8 \%$ of patients in hospital had an HCAl, with SSIs accounting for $14 \%$ of these. 89 Approximately $5 \%$ of patients who had undergone a surgical procedure were found to have developed an SSI, which can double their length of hospital stay90 and thus increase the costs of healthcare.91 These infections are associated with considerable morbidity and over one-third of postoperative deaths may be related, at least in part, to SSIs.92 More widely, a systematic review confirms that a significant number of SSIs occur following various surgical specialties in European countries and it was noteworthy that the incidence of SSI was as high as $36 \%$ in one of the studies reviewed, 93 suggesting that infections are a persistent complication of surgery 
- Hard-to-heal wounds are defined as wounds that have '...failed to proceed through an orderly and timely process to produce anatomic and functional integrity',94 and are susceptible to microbial invasion and infection which can lead to serious complications, including associated skin problems, delayed healing, wound enlargement and systemic infection.95 Hard-to-heal wounds prone to infection include venous leg ulcers, diabetic foot ulcers and pressure ulcers.95-97 Hard-to-heal wound infections are responsible for considerable morbidity and significantly contribute to escalation in the cost of healthcare.98,99 Infections usually lead to the use of increased clinician resources, more expensive products and drugs, and increased morbidity and rehabilitation time.100 The potential for infection to add significant costs to wound treatment has been highlighted in a study which showed that wound infection was one of the factors associated with the greatest duration of health professionals' time and was associated with the highest drug costs.101

Hard-to-heal wounds pose particular problems: taking weeks (or months) to heal,102 often polymicrobial and requiring broad-spectrum antimicrobial treatments.25,103 Some clinicians believe that antibiotic therapy should be continued until healing occurs, but there is no evidence to support this belief.104 Also, as wounds are at risk of recurring infections, patients are often exposed to repeated courses of antibiotic therapy.7 Since hard-to-heal wounds are highly inflamed tissues and may therefore appear infected when they are not, this may lead to inappropriate/over-prescribing of antibiotics with both infected and uninfected wounds that cause antibiotic-resistant infections.105

The threat of AMR in wounds has been recognised for over 20 years106,107 and many bacterial species (for example, Staphylococcus, Pseudomonas, Peptoniphilus, Enterobacter, Stenotrophomonas, Finegoldia and Serratia) have been identified in hard-to-heal wounds.108 Pseudomonas aeruginosa and Staphylococcus aureus are both methicillin-resistant and particularly prevalent in hard-to-heal wounds,109 burns110 and SSIs.111

The inappropriate use of antimicrobials is common to all specialties, but there are some problems that are specific to wound care: infection can be difficult to diagnose in hard-to-heal wounds; there is a lack of guidelines for the treatment of infected hard-to-heal wounds; clinicians may be unsure when to use antibiotics or be concerned that failing to use them could result in a bad outcome; and patients may demand unnecessary antibiotic therapy.112 Infection maintains inflammation and is a major contributor to delayed healing in hard-to-heal wounds. 83 The identification of microbes in a hard-toheal wound does not necessarily prove the presence of infection.112 The diagnosis of infection is based on clinical features rather than on any reliable diagnostic test,112 and these signs of infection can vary depending upon the underlying pathology.113

Antimicrobial tolerance 
Tolerance has been defined as the ability of bacteria to survive antibiotic exposure without developing resistance.114 Tolerance has also been reported to invariably precede antibiotic resistance, which indicates that preventing tolerance may offer new insight into controlling antibiotic resistance.114 This tolerance mechanism has been associated with persistent, chronic infections.115,116 Whereas antibiotic resistance is genetically induced via either mutations or horizontal gene transfer, antibiotic tolerance involves bacterial survival via dormant persister cell117 and biofilm phenotypic states.118 Although biofilm falls outside of the current definition of AMS, greater awareness of the existence, ubiquity and consequences of environmental biofilm among healthcare practitioners is crucial to improving hygiene practices, and controlling the emergence and spread of antibiotic resistance in healthcare facilities.119

\section{Antimicrobial stewardship}

There have been several global initiatives with the aim of addressing the problem of AMR.120 AMS is one global initiative for overcoming AMR to reduce the use of prescribed antibiotics.121 At its most general, 'stewardship' can be defined as the responsible planning and management of a resource7 where a successful AMS programme (ASP) optimises the use of antimicrobials to improve patient outcomes via careful programme planning and implementation based upon current knowledge and practices.122 Successful AMS and, more generally, ASPs must be a collaborative multidisciplinary team effort across the whole of a patient's care that results in the timely and optimal selection and use of antimicrobial agents (see Box 1 for key AMS actions). Nurses in particular have been identified as playing a central role in the application of stewardship to patients.123-125 The primary aim is to achieve the best clinical outcome for the patient7 and the Centers for Disease Control and Prevention (CDC) simplifies AMS as '...patients get the right antibiotics at the right time for the right duration'.126 While antibiotic stewardship programmes (ASPs) have demonstrated success in reducing costs, there is limited quality evidence of their effectiveness to reduce antibiotic resistance.127,128 The effectiveness of ASPs in reducing antibiotic-resistant infections has been variable,129-132 and significant push is required for the benefits of ASPs in reducing the incidence of antibiotic-resistant microorganisms. A recently updated Cochrane review, based on more than 200 studies from diverse settings, found that AMS interventions in hospitals result in greater compliance with treatment guidelines, reduced total duration of antimicrobial treatment, and lead to shorter lengths of hospital stays without adversely impacting patient mortality.133 Another systematic review and meta-analysis by Schuts et al.134 supported application of several AMS interventions, including guideline-directed use of empiric antimicrobials, de-escalation, switching from intravenous to oral therapy, antibiotic restrictions, therapeutic monitoring and bedside consultations in terms of improved patient outcomes, reduced costs and occurrence of adverse events. Despite the evident advantages and gains, 
managing successful AMS programmes in healthcare institutions is challenging in general and even more so in resource-constrained environments.135

Antimicrobial stewardship in wound care

The clinical, economic and patient-related consequences of wound infection place major burdens on healthcare systems.136,137 Wound infection is one of the most frequent complication of hard-to-heal wounds and can contribute to further extending the time taken for these wounds to heal.138 Therefore, effective solutions for wound infection are important. There have been several consensus documents and guidelines published to help clinical professionals make appropriate decisions about antibiotic use.7,8,11,139 Due to the recognition of AMR as a significant problem, AMS is rapidly becoming embedded within the specialist area of wound management. The British Society for Antimicrobial Chemotherapy and EWMA position paper highlights AMS as being central to appropriate use of antimicrobials (including antibiotics), improving patient outcomes, reducing microbial resistance and decreasing the spread of infections caused by MDROs.7,140 It concludes that available evidence is limited, but suggests that applying AMS principles to the care of patients with wounds should help to reduce the unnecessary use of systemic or topical antibiotic therapy, and ensure the safest and most clinically effective therapy for infected wounds.7 Antimicrobial stewardship must include consideration of both antibiotic and antiseptic use, but most of the information and guidelines that discuss the principles of antimicrobial stewardship fail to distinguish between these two groups of antimicrobials. 24

With the increasing appreciation of the importance of AMS in wound care to counter the growing threat of AMR, several initiatives have been put in place to reduce the threat of AMR. These include:

- Expedited identification and diagnosis of bacteria: early and accurate diagnosis of infection ensures the targeted and appropriate treatment of the identified microorganism to reduce the potential for using ineffective antibiotics on resistant strains and thereby avoid exacerbation of the AMR threat141

- Auditing/education (including demonstration of successful treatment outcomes): suitable monitoring and analysis of prescribing habits is important to ensure that antibiotic prescribing is appropriately within local and national guidelines. The benefits of undertaking audits to understand antimicrobial usage, and to help identify areas to target to improve AMS, have been highlighted in several studies142-145

While an AMS approach can be applied generally to all types of infection, it has been tailored to specific conditions, such as cutaneous wounds that are particularly problematic. Part of the 
development of pathways of care to prevent, minimise and treat wound infections includes reducing excessive use of dressings coated with active ingredients.

Limitations

This review is narrative, and while reviewers can summarise and make comments about a collection of studies, such reviews do not include the calculation of effect sizes that examine the strength (or lack thereof) of the effectiveness of an intervention. The quality of a narrative review may be improved by borrowing from the systematic review methodologies that are aimed at reducing bias in the selection of articles for review and employing an effective bibliographic research strategy. This may be a method that can be employed in future.

Key points

- Antimicrobial resistance to antibiotics is a burgeoning problem in healthcare, not least in the treatment of patients with infected wounds

- Antimicrobial stewardship in wound care is designed to reduce the impact of antimicrobial resistance

- Future treatment of infection in wounds will need to look at reducing the use of antibiotics and integrate alternative methods of its prevention and treatment

- Wound dressings that use physical methods (bacterial-binding) of infection management are an ideal solution to antimicrobial resistance and should be aligned with antimicrobial stewardship

- This article presents evidence that supports the integration of dressings that act by a physical means in helping to manage wound infection.

\section{Conclusions and recommendations}

Antibiotics are essential for treating wounds where there is evidence of infection, and where treatment is required to prevent further spread into deep tissues and the development of sepsis.33 However, the development of AMR has not only affected the treatment of infections in general, but also impacted upon the prevention/treatment of wound infection. The development of AMS programmes has gone some way to alleviating the challenge of $A M R$, but alternatives to antibiotics are urgently required. Wound dressings that act via bacterial-binding-which does not involve the use of any antimicrobial agents-use the properties of the dressing material to reduce bioburden by physically removing bacteria, thereby promoting wound bed progression. These wound dressings show clinically proven efficacy in reducing wound bioburden (including antibiotic resistant microorganisms), preventing wound infection, and decreasing the use of antibiotics within the 
premise of AMS via a purely physical mechanism of action, making them an important tool to fight AMR.

\section{References}

1 Magiorakos AP, Srinivasan A, Carey RB et al. Multidrug-resistant, extensively drug-resistant and pandrug-resistant bacteria: an international expert proposal for interim standard definitions for acquired resistance. Clin Microbiol Infect 2012; 18(3):268-281. https://doi.org/10.1111/j.1469$\underline{0691.2011 .03570 . x}$

2 Woodmansey EJ, Roberts CD. Appropriate use of dressings containing nanocrystalline silver to support antimicrobial stewardship in wounds. Int Wound J 2018; 15(6):1025-1032. https://doi.org/10.1111/iwj.12969

3 Fernandes P, Martens E. Antibiotics in late clinical development. Biochem Pharmacol 2017; 133:152163. https://doi.org/10.1016/j.bcp.2016.09.025

4 Wright $\mathrm{H}$, Bonomo RA, Paterson DL. New agents for the treatment of infections with Gram-negative bacteria: restoring the miracle or false dawn? Clin Microbiol Infect 2017; 23(10):704-712. https://doi.org/10.1016/j.cmi.2017.09.001

5 Gajdács M. The concept of an ideal antibiotic: implications for drug design. Molecules 2019; 24(5):892. https://doi.org/10.3390/molecules24050892

6 European Centre for Disease Control. Summary of the latest data on antibiotic consumption in European Union: 2018. 2019. https://tinyurl.com/2kb24p7u (accessed 18 November 2020)

7 Lipsky BA, Dryden M, Gottrup F et al. Antimicrobial stewardship in wound care: a position paper for the British Society for Antimicrobial Chemotherapy and European Wound Management Association. J Antimicrob Chemother 2016; 71(11):3026-3035. https://doi.org/10.1093/jac/dkw287

8 Cooper R, Kirketerp-Møller K. Non-antibiotic antimicrobial interventions and antimicrobial stewardship in wound care. J Wound Care 2018; 27(6):355-377. https://doi.org/10.12968/jowc.2018.27.6.355

9 European Wound Management Association. EWMA podcast: antimicrobial stewardship in wound management. https://tinyurl.com/y5wv6ts5 (accessed 30 November 2020)

10 Green BN, Johnson CD, Adams A. Writing narrative literature reviews for peer-reviewed journals: secrets of the trade. J Chiropr Med 2006; 5(3):101-117. https://doi.org/10.1016/S08993467(07)60142-6 
11 Gottrup F, Apelqvist J, Bjarnsholt T et al. EWMA document: antimicrobials and non-healing wounds: evidence, controversies and suggestions. J Wound Care 2013; 22(Suppl 5):S1-S89. https://doi.org/10.12968/jowc.2013.22.Sup5.S1

12 Gompelman M, van Asten SA, Peters EJ. Update on the role of infection and biofilms in wound healing: pathophysiology and treatment. Plast Reconstr Surg 2016; 138(Suppl 3):61S-70S. https://doi.org/10.1097/PRS.0000000000002679

13 Sass $\mathrm{P}$, Brötz-Oesterhelt $\mathrm{H}$. Bacterial cell division as a target for new antibiotics. Curr Opin Microbiol 2013; 16(5):522-530. https://doi.org/10.1016/i.mib.2013.07.006

14 Rippon MG, Rogers AA, Sellars L et al. Effectiveness of a nonmedicated wound dressing on attached and biofilm encased bacteria: laboratory and clinical evidence. J Wound Care 2018; 27(3):146-155. https://doi.org/10.12968/jowc.2018.27.3.146

15 Rippon MG, Rogers AA, Westgate S. Treating drug-resistant wound pathogens with non-medicated dressings: an in vitro study. J Wound Care 2019; 28(9):629-638. https://doi.org/10.12968/jowc.2019.28.9.629

16 da Silveira Teixeira D, de Figueiredo MA, Cherubini K et al. The topical effect of chlorhexidine and povidone-iodine in the repair of oral wounds: a review. Stomatologija 2019; 21(2):35-41

17 Bigliardi PL, Alsagoff SA, El-Kafrawi HY et al. Povidone iodine in wound healing: a review of current concepts and practices. Int J Surg 2017; 44:260-268. https://doi.org/10.1016/j.ijsu.2017.06.073

18 Fitzgerald DJ, Renick PJ, Forrest EC et al. Cadexomer iodine provides superior efficacy against bacterial wound biofilms in vitro and in vivo. Wound Repair Regen 2017; 25(1):13-24. https://doi.org/10.1111/wrr.12497

19 Fjeld H, Lingaas E. Polyhexanide: safety and efficacy as an antiseptic. Tidsskr Nor Laegeforen 2016; 136(8):707-711. https://doi.org/10.4045/tidsskr.14.1041

20 Möhler JS, Sim W, Blaskovich MA et al. Silver bullets: a new lustre on an old antimicrobial agent. Biotechnol Adv 2018; 36(5):1391-1411. https://doi.org/10.1016/j.biotechadv.2018.05.004

21 White R. Manuka honey in wound management: greater than the sum of its parts? J Wound Care 2016; 25(9):539-543. https://doi.org/10.12968/jowc.2016.25.9.539

22 Ibrahim N, Wong S, Mohamed I et al. Wound healing properties of selected natural products. Int J Environ Res Public Health 2018; 15(11):2360. https://doi.org/10.3390/ijerph15112360 
23 Vijayakumar R, Sandle T. A review on biocide reduced susceptibility due to plasmid-borne antiseptic-resistant genes: special notes on pharmaceutical environmental isolates. J Appl Microbiol 2019; 126(4): 1011-1022. https://doi.org/10.1111/jam.14118

24 Leaper DJ, Roberts CD. Antiseptic resistance: antimicrobial stewardship and silver dressings. Wounds International 2017; 8(2): 27-31

25 Lipsky BA, Hoey C. Topical antimicrobial therapy for treating chronic wounds. Clin Infect Dis 2009; 49(10):1541-1549. https://doi.org/10.1086/644732

26 Holder IA, Boyce ST. Assessment of the potential for microbial resistance to topical use of multiple antimicrobial agents. Wound Repair Regen 1999; 7(4):238-243. https://doi.org/10.1046/i.1524475X.1999.00238.x

27 Öien RF, Forssell HW. Ulcer healing time and antibiotic treatment before and after the introduction of the Registry of Ulcer Treatment: an improvement project in a national quality registry in Sweden. BMJ Open 2013; 3(8):e003091. https://doi.org/10.1136/bmjopen-2013-003091

28 Liu JX, Werner J, Kirsch T et al. Cytotoxicity evaluation of chlorhexidine gluconate on human fibroblasts, myoblasts, and osteoblasts. J Bone Jt Infect 2018; 3(4):165-172. https://doi.org/10.7150/jbji.26355

29 Thomas GW, Rael LT, Bar-Or R et al. Mechanisms of delayed wound healing by commonly used antiseptics. J Trauma Inj Infect Crit Care 2009; 66(1):82-91. https://doi.org/10.1097/TA.0b013e31818b146d

30 Liu JX, Werner JA, Buza JA et al. Povidone-iodine solutions inhibit cell migration and survival of osteoblasts, fibroblasts, and myoblasts. Spine 2017; 42(23):1757-1762. https://doi.org/10.1097/BRS.0000000000002224

31 Abdel-Sayed P, Tornay D, Hirt-Burri N et al. Implications of chlorhexidine use in burn units for wound healing. Burns 2020; 46(5):1150-1156. https://doi.org/10.1016/i.burns.2019.12.008

32 Metcalf D, Parsons D, Bowler P. A next-generation antimicrobial wound dressing: a real-life clinical evaluation in the UK and Ireland. J Wound Care 2016; 25(3):132-138. https://doi.org/10.12968/jowc.2016.25.3.132

33 Edwards-Jones V, Tickle J, Nichols E et al. Should antimicrobial dressings be classified according to their activity and be subject to stewardship like antibiotics? Wounds UK 2019; 15(2):20-23 
34 Wilkinson A, Ebata A, MacGregor H. Interventions to reduce antibiotic prescribing in LMICs: a scoping review of evidence from human and animal health systems. Antibiotics 2018; 8(1):2. https://doi.org/10.3390/antibiotics8010002

35 Totty JP, Bua N, Smith GE et al. Dialkylcarbamoyl chloride (DACC)-coated dressings in the management and prevention of wound infection: a systematic review. J Wound Care 2017; 26(3):107114. https://doi.org/10.12968/jowc.2017.26.3.107

36 Krasowska A, Sigler K. How microorganisms use hydrophobicity and what does this mean for human needs? Front Cell Infect Microbiol 2014; 4:112. https://doi.org/10.3389/fcimb.2014.00112

37 Ljungh $\AA$, Wadström T. Growth conditions influence expression of cell surface hydrophobicity of staphylococci and other wound infection pathogens. Microbiol Immunol 1995; 39(10):753-757. https://doi.org/10.1111/j.1348-0421.1995.tb03267.x

38 Cooper R, Jenkins L. Binding of two bacterial biofilms to dialkyl carbamoyl chloride (DACC)-coated dressings in vitro. J Wound Care 2016; 25(2):76-82. https://doi.org/10.12968/jowc.2016.25.2.76

39 Ljungh $\AA$, Yanagisawa N, Wadström T. Using the principle of hydrophobic interaction to bind and remove wound bacteria. J Wound Care 2006; 15(4):175-180. https://doi.org/10.12968/jowc.2006.15.4.26901

40 Stanirowski PJ, Kociszewska A, Cendrowski K, Sawicki W. Dialkylcarbamoyl chloride-impregnated dressing for the prevention of surgical site infection in women undergoing cesarean section: a pilot study. Arch Med Sci 2016; 5(5):1036-1042. https://doi.org/10.5114/aoms.2015.47654

41 Probst A, Norris R, Cutting K. Cutimed Sorbact made easy. Wounds International 2012; 3(2). https://www.woundsinternational.com/download/resource/6118 (accessed 10 March 2021)

42 Ronner AC, Curtin J, Karami N, Ronner U. Adhesion of meticillinresistant Staphylococcus aureus to DACC-coated dressings. J Wound Care 2014; 23(10):484-488. https://doi.org/10.12968/jowc.2014.23.10.484

43 Bua N, Smith GE, Totty JP et al. Dialkylcarbamoyl chloride dressings in the prevention of surgical site infections after nonimplant vascular surgery. Ann Vasc Surg 2017; 44:387-392. https://doi.org/10.1016/j.avsg.2017.03.198

44 Richardson LA. Understanding and overcoming antibiotic resistance. PLoS Biol 2017; 15(8):e2003775. https://doi.org/10.1371/journal.pbio.2003775 
45 Hoffman JM, Shah ND, Vermeulen LC et al. Projecting future drug expenditures-2007. Am J Health Syst Pharm 2007; 64(3):298-314. https://doi.org/10.2146/ajhp060545

46 Wise R, Hart T, Cars $O$ et al. Antimicrobial resistance. BMJ 1998; 317(7159):609-610. https://doi.org/10.1136/bmj.317.7159.609

47 John JF Jr, Fishman NO. Programmatic role of the infectious diseases physician in controlling antimicrobial costs in the hospital. Clin Infect Dis 1997; 24(3):471-485. https://doi.org/10.1093/clinids/24.3.471

48 Smieszek T, Pouwels KB, Dolk FC et al. Potential for reducing inappropriate antibiotic prescribing in English primary care. J Antimicrob Chemother 2018; 73(Suppl 2):ii36-ii43. https://doi.org/10.1093/jac/dkx500

49 Dellit TH, Owens RC, McGowan JE Jr et al.; Infectious Diseases Society of America; Society for Healthcare Epidemiology of America. Infectious Diseases Society of America and the Society for Healthcare Epidemiology of America guidelines for developing an institutional program to enhance antimicrobial stewardship. Clin Infect Dis 2007; 44(2):159-177. https://doi.org/10.1086/510393

50 Fleming-Dutra KE, Hersh AL, Shapiro DJ et al. Prevalence of inappropriate antibiotic prescriptions among US ambulatory care visits, 2010-2011. JAMA 2016; 315(17):1864-1873. https://doi.org/10.1001/jama.2016.4151

51 Edwards-Jones V, Spruce P. Antimicrobial stewardship: what it means in tissue viability. Wounds UK 2019; 15(1):64-69

52 World Health Organization. Ten threats to global health in 2019. https://tinyurl.com/8zw66k33 (accessed 10 March 2021)

53 Klein EY, Van Boeckel TP, Martinez EM et al. Global increase and geographic convergence in antibiotic consumption between 2000 and 2015. Proc Natl Acad Sci U S A 2018; 115(15):E3463-E3470. https://doi.org/10.1073/pnas.1717295115

54 Nathan C. Resisting antimicrobial resistance. Nat Rev Microbiol 2020; 18(5):259-260. https://doi.org/10.1038/s41579-020-0348-5

55 Ventola CL. The antibiotic resistance crisis: part 1: causes and threats. P T 2015; 40(4):277-283 56 O'Neill J. Tackling drug-resistant infections globally: final report and recommendation. The review on antimicrobial resistance. 2016. https://tinyurl.com/cb5zp64b (accessed 18 November 2020) 
57 Soriano A, Stefani S, Pletz MW, Menichetti F; Italian Group for Antimicrobial Stewardship (GISA). Antimicrobial stewardship in patients with acute bacterial skin and skin-structure infections: An international Delphi consensus. J Glob Antimicrob Resist 2020; 22:296-301. https://doi.org/10.1016/i.jgar.2020.02.002

58 Hermsen ED, Jenkins R, Vlaev I et al. The role of the private sector in advancing antimicrobial stewardship: recommendations from the Global Chief Medical Officers' Network. Popul Health Manag 2020; 2020: https://doi.org/10.1089/pop.2020.0027

59 Smith DR, Dolk FC, Pouwels KB et al. Defining the appropriateness and inappropriateness of antibiotic prescribing in primary care. J Antimicrob Chemother 2018; 73(Suppl 2):ii11-ii18. https://doi.org/10.1093/jac/dkx503

60 O'Neill J. Review on antimicrobial resistance: tackling drug-resistant infections globally. Antimicrobial resistance: tackling a crisis for the health and wealth of nations. 2014. https://tinyurl.com/zmylsav (accessed 30 November 2020)

61 Infectious Diseases Society of America. Facts about antibiotic resistance. 2015. https://tinyurl.com/3j29b9x8 (accessed 1 December 2020)

62 World Health Organization: antimicrobial resistance. Report by the Secretariat. 2017. https://apps.who.int/iris/handle/10665/274735 (accessed 4 December 2020)

63 Orsi GB, Falcone $M$, Venditti $M$. Surveillance and management of multidrug-resistant microorganisms. Expert Rev Anti Infect Ther 2011; 9(8):653-679. https://doi.org/10.1586/eri.11.77

64 Cassini A, Högberg LD, Plachouras D et al.; Burden of AMR Collaborative Group. Attributable deaths and disability-adjusted life-years caused by infections with antibiotic-resistant bacteria in the EU and the European Economic Area in 2015: a population-level modelling analysis. Lancet Infect Dis 2019; 19(1):56-66. https://doi.org/10.1016/S1473-3099(18)30605-4

65 Luyt CE, Bréchot N, Trouillet JL, Chastre J. Antibiotic stewardship in the intensive care unit. Crit Care 2014; 18(5):480. https://doi.org/10.1186/s13054-014-0480-6

66 Timsit JF, Bassetti M, Cremer O et al. Rationalizing antimicrobial therapy in the ICU: a narrative review. Intensive Care Med 2019; 45(2):172-189. https://doi.org/10.1007/s00134-019-05520-5

67 Wounds UK. The role of non-medicated dressings for the management of wound infection. 2020. https://tinyurl.com/jvmad2xx (accessed 10 March 2021) 
68 Frykberg RG, Banks J. Challenges in the treatment of chronic wounds. Adv Wound Care 2015; 4(9):560-582. https://doi.org/10.1089/wound.2015.0635

69 Chadwick P, Ousey K. Bacterial-binding dressings in the management of wound healing and infection prevention: a narrative review. J Wound Care 2019; 28(6):370-382. https://doi.org/10.12968/jowc.2019.28.6.370

70 Wounds UK. Best practice statement: antimicrobial stewardship strategies for wound management. 2020. https://tinyurl.com/79xtz8t3 (accessed 19 November 2020)

71 Oliveira A, Simões S, Ascenso A, Reis CP. Therapeutic advances in wound healing. J Dermatolog Treat 2020; 26:1-21. https://doi.org/10.1080/09546634.2020.1730296

72 Guo S, DiPietro LA. Factors affecting wound healing. J Dent Res 2010; 89(3):219-229. https://doi.org/10.1177/0022034509359125

73 Cañedo-Dorantes L, Cañedo-Ayala M. Skin acute wound healing: a comprehensive review. Int J Inflamm 2019; 2019:1-15. https://doi.org/10.1155/2019/3706315

74 Nunan R, Harding KG, Martin P. Clinical challenges of chronic wounds: searching for an optimal animal model to recapitulate their complexity. Dis Model Mech 2014; 7(11):1205-1213. https://doi.org/10.1242/dmm.016782

75 Kalan L, Zhou M, Labbie M, Willing B. Measuring the microbiome of chronic wounds with use of a topical antimicrobial dressing: a feasibility study. PLoS One 2017; 12(11):e0187728. https://doi.org/10.1371/journal.pone.0187728

$76 \mathrm{Xu} \mathrm{Z}$, Hsia HC. The impact of microbial communities on wound healing: a review. Ann Plast Surg 2018; 81(1):113-123. https://doi.org/10.1097/SAP.0000000000001450

77 Bjarnsholt T, Cooper R, Wolcott RD et al.; Wounds International. Position document: management of biofilm. 2016. https://tinyurl.com/yjtu6m88 (accessed 10 March 2021)

78 Roy R, Tiwari M, Donelli G, Tiwari V. Strategies for combating bacterial biofilms: a focus on antibiofilm agents and their mechanisms of action. Virulence 2018; 9(1):522-554. https://doi.org/10.1080/21505594.2017.1313372

79 Kalan LR, Brennan MB. The role of the microbiome in nonhealing diabetic wounds. Ann N Y Acad Sci 2019; 1435(1):79-92. https://doi.org/10.1111/nyas.13926

80 Metcalf D, Bowler P. Biofilm delays wound healing: a review of the evidence. Burns Trauma 2013; 1(1):5-12. https://doi.org/10.4103/2321-3868.113329 
81 Nguyen KT, Seth AK, Hong SJ et al. Deficient cytokine expression and neutrophil oxidative burst contribute to impaired cutaneous wound healing in diabetic, biofilm-containing chronic wounds. Wound Repair Regen 2013; 21(6):833-841. https://doi.org/10.1111/wrr.12109

82 Wolcott R, Sanford N, Gabrilska R et al. Microbiota is a primary cause of pathogenesis of chronic wounds. J Wound Care 2016; 25(Suppl 10):S33-S43. https://doi.org/10.12968/jowc.2016.25.Sup10.S33

83 Leaper D, Assadian O, Edmiston CE. Approach to chronic wound infections. Br J Dermatol 2015; 173(2):351-358. https://doi.org/10.1111/bjd.13677

84 Deeth M. A closer look at the wound infection continuum. Br J Community Nurs 2017; 22(Suppl 12): $\$ 48-\$ 50$

85 Sibbald RG, Orsted H, Schultz GS et al.; International Wound Bed Preparation Advisory Board; Canadian Chronic Wound Advisory Board. Preparing the wound bed 2003: focus on infection and inflammation. Ostomy Wound Manage 2003; 49(11):24-51

86 Patel S. Investigating: wound infection. Wound Essentials 2010; 5:40-47

87 Public Health England. Surveillance of surgical site infections in NHS hospitals in England, April 2016 to March 2017. 2017. https://tinyurl.com/yaun6jh2 (accessed 1 December 2020)

88 Liu Z, Dumville JC, Norman G et al. Intraoperative interventions for preventing surgical site infection: an overview of Cochrane Reviews. Cochrane Database Syst Rev 2018; 2:CD012653. https://doi.org/10.1002/14651858.CD012653.pub2

89 National Collaborating Centre for Women's and Children's Health (UK). Surgical site infection: prevention and treatment of surgical site Infection. London: RCOG Press (NICE Clinical Guidelines, No. 74). 2008. https://www.ncbi.nlm.nih.gov/books/NBK53731 (accessed 20 November 2020)

90 Coello R, Charlett A, Wilson J et al. Adverse impact of surgical site infections in English hospitals. J Hosp Infect 2005; 60(2):93-103. https://doi.org/10.1016/j.jhin.2004.10.019

91 Broex EC, van Asselt AD, Bruggeman CA, van Tiel FH. Surgical site infections: how high are the costs? J Hosp Infect 2009; 72(3):193-201. https://doi.org/10.1016/j.jhin.2009.03.020

92 National Institute for Health and Care Excellence. Surgical site infections: prevention and treatment. NICE Guideline, NG125. 2019. https://www.nice.org.uk/guidance/ng125 (accessed 20 November 2020) 
93 Badia JM, Casey AL, Petrosillo N et al. Impact of surgical site infection on healthcare costs and patient outcomes: a systematic review in six European countries. J Hosp Infect 2017; 96(1):1-15. https://doi.org/10.1016/i.jhin.2017.03.004

94 Lazarus GS, Cooper DM, Knighton DR et al. Definitions and guidelines for assessment of wounds and evaluation of healing. Arch Dermatol 1994; 130(4):489-493

95 Pugliese DJ. Infection in venous leg ulcers: considerations for optimal management in the elderly. Drugs Aging 2016; 33(2):87-96. https://doi.org/10.1007/s40266-016-0343-8

96 Everett E, Mathioudakis N. Update on management of diabetic foot ulcers. Ann N Y Acad Sci 2018; 1411(1):153-165. https://doi.org/10.1111/nyas.13569

97 Wong D, Holtom P, Spellberg B. Osteomyelitis complicating sacral pressure ulcers: whether or not to treat with antibiotic therapy. Clin Infect Dis 2019; 68(2):338-342. https://doi.org/10.1093/cid/ciy559

98 Siddiqui AR, Bernstein JM. Chronic wound infection: facts and controversies. Clin Dermatol 2010; 28(5):519-526. https://doi.org/10.1016/j.clindermatol.2010.03.009

99 Bui UT, Finlayson K, Edwards H. Risk factors for infection in patients with chronic leg ulcers: a survival analysis. Int J Clin Pract 2018; 72(12):e13263. https://doi.org/10.1111/ijcp.13263

100 Nussbaum SR, Carter MJ, Fife CE et al. An economic evaluation of the impact, cost, and Medicare policy implications of chronic nonhealing wounds. Value Health 2018; 21(1):27-32. https://doi.org/10.1016/i.jval.2017.07.007

101 Charlesworth B, Pilling C, Chadwick P, Butcher M. Dressing-related trauma: clinical sequelae and resource utilization in a UK setting. Clinicoecon Outcomes Res 2014; 6:227-239

102 Martin P, Nunan R. Cellular and molecular mechanisms of repair in acute and chronic wound healing. Br J Dermatol 2015; 173(2):370-378. https://doi.org/10.1111/bjd.13954

103 Han A, Zenilman JM, Melendez JH et al. The importance of a multifaceted approach to characterizing the microbial flora of chronic wounds. Wound Repair Regen 2011; 19(5):532-541. https://doi.org/10.1111/j.1524-475X.2011.00720.x

104 Abbas M, Uçkay I, Lipsky BA. In diabetic foot infections antibiotics are to treat infection, not to heal wounds. Expert Opin Pharmacother 2015; 16(6):821-832. https://doi.org/10.1517/14656566.2015.1021780 
105 Howell-Jones RS, Price PE, Howard AJ, Thomas DW. Antibiotic prescribing for chronic skin wounds in primary care. Wound Repair Regen 2006; 14(4):387-393. https://doi.org/10.1111/i.1743$\underline{6109.2006 .00144 . x}$

106 Dow G, Browne A, Sibbald RG. Infection in chronic wounds: controversies in diagnosis and treatment. Ostomy Wound Manage 1999; 45(8):23-27

107 Filius PM, Gyssens IC. Impact of increasing antimicrobial resistance on wound management. Am J Clin Dermatol 2002; 3(1):1-7. https://doi.org/10.2165/00128071-200203010-00001

108 Rahim K, Saleha S, Zhu X et al. Bacterial contribution in chronicity of wounds. Microb Ecol 2017; 73(3):710-721. https://doi.org/10.1007/s00248-016-0867-9

109 Saltoglu N, Ergonul O, Tulek $\mathrm{N}$ et al.; Turkish Society of Clinical Microbiology and Infectious Diseases, Diabetic Foot Infections Study Group. Influence of multidrug resistant organisms on the outcome of diabetic foot infection. Int J Infect Dis 2018; 70:10-14. https://doi.org/10.1016/j.ijid.2018.02.013

110 Rashid A, Saqib M, Deeba F, Khan JA. Microbial profile of burn wound infections and their antibiotic sensitivity patterns at burn unit of allied hospital Faisalabad. Pak J Pharm Sci 2019; 32(Suppl 1):247-254

111 Călina D, Docea AO, Rosu L et al. Antimicrobial resistance development following surgical site infections. Mol Med Rep 2017; 15(2):681-688. https://doi.org/10.3892/mmr.2016.6034

112 Price A, DaCosta F, Gubb S et al. An audit of antimicrobial prescribing and microbiological sampling in a complex wound clinic. Wounds UK 2019; 15(2):24-29

113 Cutting KF, White R. Defined and refined: criteria for identifying wound infection revisited. $\mathrm{Br}$ J Community Nurs 2004; 9(Suppl 1):S6-S15. https://doi.org/10.12968/bicn.2004.9.Sup1.12495

114 Levin-Reisman I, Ronin I, Gefen O et al. Antibiotic tolerance facilitates the evolution of resistance. Science 2017; 355(6327):826-830. https://doi.org/10.1126/science.aaj2191

115 Martínez JL, Rojo F. Metabolic regulation of antibiotic resistance. FEMS Microbiol Rev 2011; 35(5):768-789. https://doi.org/10.1111/j.1574-6976.2011.00282.x

116 Yan J, Bassler BL. Surviving as a community: antibiotic tolerance and persistence in bacterial biofilms. Cell Host Microbe 2019; 26(1):15-21. https://doi.org/10.1016/j.chom.2019.06.002

117 Conlon BP, Nakayasu ES, Fleck LE et al. Activated ClpP kills persisters and eradicates a chronic biofilm infection. Nature 2013; 503(7476):365-370. https://doi.org/10.1038/nature12790 
118 Olsen I. Biofilm-specific antibiotic tolerance and resistance. Eur J Clin Microbiol Infect Dis 2015; 34(5):877-886. https://doi.org/10.1007/s10096-015-2323-z

119 Bowler P, Murphy C, Wolcott R. Biofilm exacerbates antibiotic resistance: Is this a current oversight in antimicrobial stewardship? Antimicrob Resist Infect Control 2020; 9(1):162. https://doi.org/10.1186/s13756-020-00830-6

120 Ousey K, Blackburn J. Understanding antimicrobial resistance and antimicrobial stewardship in wound management. Wounds UK 2020; 16(2):36-39

121 Seok H, Jeon JH, Park DW. Antimicrobial therapy and antimicrobial stewardship in sepsis. Infect Chemother 2020; 52(1):19-30. https://doi.org/10.3947/ic.2020.52.1.19

122 Resman F. Antimicrobial stewardship programs; a two-part narrative review of step-wise design and issues of controversy Part I: stepwise design of an antimicrobial stewardship program. Ther Adv Infect Dis 2020; 7. https://doi.org/10.1177/2049936120933187

123 Olans RD, Hausman NB, Olans RN. Nurses and antimicrobial stewardship: past, present, and future. Infect Dis Clin North Am 2020; 34(1):67-82. https://doi.org/10.1016/j.idc.2019.10.008

124 Ervin KE, Tse KC, Reid C, Smith E. Exploring barriers to and enablers of antimicrobial stewardship in rural health services. Infect Dis Health 2021; 26(1):11-21. https://doi.org/10.1016/i.idh.2020.08.003

125 van Huizen P, Kuhn L, Russo PL, Connell CJ. The nurses' role in antimicrobial stewardship: a scoping review. Int J Nurs Stud 2021; 113:103772. https://doi.org/10.1016/j.ijnurstu.2020.103772

126 Centers for Disease Control and Prevention. Overview and evidence to support appropriate antibiotic use. 2019. https://www.cdc.gov/antibiotic-use/healthcare/evidence.html (accessed 30 November 2020)

127 Rüttimann S, Keck B, Hartmeier C et al. Long-term antibiotic cost savings from a comprehensive intervention program in a medical department of a university-affiliated teaching hospital. Clin Infect Dis 2004; 38(3):348-356. https://doi.org/10.1086/380964

128 Lutters M, Harbarth S, Janssens JP et al. Effect of a comprehensive, multidisciplinary, educational program on the use of antibiotics in a geriatric university hospital. J Am Geriatr Soc 2004; 52(1):112116. https://doi.org/10.1111/j.1532-5415.2004.52019.x 
129 Davey P, Brown E, Charani E et al. Interventions to improve antibiotic prescribing practices for hospital inpatients. Cochrane Database Syst Rev 2013; 4(4):CD003543. https://doi.org/10.1002/14651858.CD003543.pub3

130 Apisarnthanarak A, Pinitchai U, Warachan B et al. Effectiveness of infection prevention measures featuring advanced source control and environmental cleaning to limit transmission of extremely-drug resistant Acinetobacter baumannii in a Thai intensive care unit: an analysis before and after extensive flooding. Am J Infect Control 2014; 42(2):116-121. https://doi.org/10.1016/j.ajic.2013.09.025

131 Peto Z, Benko R, Matuz M, et al. Results of a local antibiotic management program on antibiotic use in a tertiary intensive care unit in Hungary. Infection 2008; 36(6):560-564. https://doi.org/10.1007/s15010-008-7377-8

132 Tartof SY, Chen LH, Tian Y et al. Do inpatient antimicrobial stewardship programs help us in the battle against antimicrobial resistance? Clin Infect Dis 2020; ciaa1004. https://doi.org/10.1093/cid/ciaa1004

133 Davey P, Marwick CA, Scott CL et al. Interventions to improve antibiotic prescribing practices for hospital inpatients. Cochrane Database Syst Rev 2017; 2:CD003543. https://doi.org/10.1002/14651858.CD003543.pub4

134 Schuts EC, Hulscher ME, Mouton JW et al. Current evidence on hospital antimicrobial stewardship objectives: a systematic review and meta-analysis. Lancet Infect Dis 2016; 16(7):847-856. https://doi.org/10.1016/S1473-3099(16)00065-7

135 Kakkar AK, Shafiq N, Singh G et al. Antimicrobial stewardship programs in resource constrained environments: understanding and addressing the need of the systems. Front Public Health 2020; 8:140. https://doi.org/10.3389/fpubh.2020.00140

136 Roberts CD, Leaper DJ, Assadian O. The role of topical antiseptic agents within antimicrobial stewardship strategies for prevention and treatment of surgical site and chronic open wound infection. Adv Wound Care 2017; 6(2):63-71. https://doi.org/10.1089/wound.2016.0701

137 Lindholm C, Searle R. Wound management for the 21st century: combining effectiveness and efficiency. Int Wound J 2016; 13(Suppl 2):5-15. https://doi.org/10.1111/iwj.12623

138 Edwards R, Harding KG. Bacteria and wound healing. Curr Opin Infect Dis 2004; 17(2):91-96. https://doi.org/10.1097/00001432-200404000-00004 
139 Swanson T, Angel D, Sussman G et al.; International Wound Infection Institute. Wound infection in clinical practice: principles of best practice. https://tinyurl.com/45r47yu9 (accessed 19 November 2020)

140 Dyar OJ, Huttner B, Schouten J, Pulcini C; ESGAP (ESCMID Study Group for Antimicrobial stewardshiP). What is antimicrobial stewardship? Clin Microbiol Infect 2017; 23(11):793-798. https://doi.org/10.1016/j.cmi.2017.08.026

141 Caliendo AM, Gilbert DN, Ginocchio CC et al.; Infectious Diseases Society of America (IDSA). Better tests, better care: improved diagnostics for infectious diseases. Clin Infect Dis 2013; 57(Suppl 3):S139S170. https://doi.org/10.1093/cid/cit578

142 Tandan M, O'Connor R, Burns K et al. A comparative analysis of prophylactic antimicrobial use in long-term care facilities in Ireland, 2013 and 2016. Euro Surveill 2019; 24(11):1800102. https://doi.org/10.2807/1560-7917.ES.2019.24.11.1800102

143 Mohamed R, Wall J, Arumainathan R et al. Assessing antibiotic stewardship using the surgical site infection prevention bundle. $\mathrm{Br} J$ Hosp Med 2018; 79(11):643-647. https://doi.org/10.12968/hmed.2018.79.11.643

144 National Institute for Health and Care Excellence. NICEimpact antimicrobial resistance. 2018. https://tinyurl.com/tr6538c (accessed 5 December 2020)

145 Tedeschi S, Trapani F, Giannella M et al. An antimicrobial stewardship program based on systematic infectious disease consultation in a rehabilitation facility. Infect Control Hosp Epidemiol 2017; 38(1):76-82. https://doi.org/10.1017/ice.2016.233

146 Pirie G, Duguid K, Timmons J. Cutimed Sorbact gel: a new infection management dressing. Wounds UK 2009; 5(2):74-78

147 Dryden M, Johnson AP, Ashiru-Oredope D, Sharland M. Using antibiotics responsibly: right drug, right time, right dose, right duration. J Antimicrob Chemother 2011; 66(11):2441-2443. https://doi.org/10.1093/jac/dkr370

148 Wadström T, Björnberg S, Hjertén S. Hydrophobized wound dressing in the treatment of experimental Staphylococcus aureus infections in the young pig. Acta Pathologica Microbiologica Scandinavica Series B: Microbiology 1985; 93B(1-6):359-363. https://doi.org/10.1111/j.1699$\underline{0463.1985 . t b 02901 . x}$

149 Bowler PG, Jones SA, Davies BJ, Coyle E. Infection control properties of some wound dressings. J Wound Care 1999; 8(10):499-502. https://doi.org/10.12968/jowc.1999.8.10.26356 
150 Brackman G, De Meyer L, Nelis HJ, Coenye T. Biofilm inhibitory and eradicating activity of wound care products against Staphylococcus aureus and Staphylococcus epidermidis biofilms in an in vitro chronic wound model. J Appl Microbiol 2013; 114(6):1833-1842. https://doi.org/10.1111/iam.12191 151 Geroult S, Phillips RO, Demangel C. Adhesion of the ulcerative pathogen Mycobacterium ulcerans to DACC-coated dressings. J Wound Care 2014; 23(8):417-424. https://doi.org/10.12968/jowc.2014.23.8.417

152 Meberg A, Schøyen R. Hydrophobic material in routine umbilical cord care and prevention of infections in newborn infants. Scand J Infect Dis 1990; 22(6):729-733. https://doi.org/10.3109/00365549009027128

153 Romain B, Mielcarek M, Delhorme JB et al.; SORKYSA group. Dialkylcarbamoyl chloride-coated versus alginate dressings after pilonidal sinus excision: a randomized clinical trial (SORKYSA study). BJS Open 2020; 4(2):225-231. https://doi.org/10.1002/bjs5.50259

154 Totty JP, Hitchman LH, Cai PL et al. A pilot feasibility randomised clinical trial comparing dialkylcarbamoylchloride-coated dressings versus standard care for the primary prevention of surgical site infection. Int Wound J 2019; 16(4):883-890. https://doi.org/10.1111/iwj.13113

155 Stanirowski PJ, Bizoń M, Cendrowski K, Sawicki W. Randomized controlled trial evaluating dialkylcarbamoyl chloride impregnated dressings for the prevention of surgical site infections in adult women undergoing cesarean section. Surg Infect 2016; 17(4):427-435. https://doi.org/10.1089/sur.2015.223

156 Kammerlander G, Locher E, Suess-Burghart A et al. An investigation of Cutimed Sorbact as an antimicrobial alternative in wound management. Wounds UK 2008; 4(2):10-18

157 Kleintjes WG, Boggenpoel A, Diango K. A prospective descriptive study of Cutimed Sorbact used as a skin substitute for the treatment of partial thickness burn wounds. Prof Nurs Today 2018; 22(2):33-38

158 Dwiyana RF, Gondokaryono SP, Rahardja Jl et al. Clinical efficacy of dialkylcarbamoylchloridecoated cotton acetate dressing versus combination of normal saline dressing and $2 \%$ mupirocin ointment in infected wounds of epidermolysis bullosa. Dermatol Ther 2019; 32(5):e13047. https://doi.org/10.1111/dth.13047

159 Kleintjes WG, Schoeman D, Collier L. A pilot study of Cutimed Sorbact versus ACTICOAT versus Silverlon for the treatment of burn wounds in a South African adult burn unit. Prof Nurs Today 2017; 21(3):36-44 
160 Kusu-Orkar TE, Islam U, Hall B et al. The use of a non-medicated dressing for superficial-partial thickness burns in children: a case series and review. Scars Burn Heal 2019; 5:2059513119896954. https://doi.org/10.1177/2059513119896954

161 Ciliberti M, De Lara F, Serra G et al. The effect of a bacteria- and fungi-binding mesh dressing on the bacterial load of pressure ulcers treated with negative pressure wound therapy: a pilot study. Wounds 2016; 28(11):408-420

162 Mosti G, Magliaro A, Mattaliano V et al. Comparative study of two antimicrobial dressings in infected leg ulcers: a pilot study. J Wound Care 2015; 24(3):121-127. https://doi.org/10.12968/jowc.2015.24.3.121

163 Mussi C, Salvioli G. Clinical evaluation of Sorbact (bacteria absorbing dressing) in the treatment of infected pressure sores. Acta Vulcanol 2004; 2(1-2):9-11

164 Haycocks S, Chadwick P. Use of DACC-coated dressings in diabetic foot ulcers: a case series. Diabet Foot J 2011; 14(3):133-137

165 Hampton S. An evaluation of the efficacy of Cutimed Sorbact in different types of non-healing wounds. Wounds UK 2007; 3(4):113-119

166 Gentili V, Gianesini S, Balboni PG et al. Panbacterial real-time PCR to evaluate bacterial burden in chronic wounds treated with Cutimed Sorbact. Eur J Clin Microbiol Infect Dis 2012; 31(7):1523-1529. https://doi.org/10.1007/s10096-011-1473-x

167 Sibbald G, Woo K, Coutts P. The effectiveness of a new antimicrobial dressing with microbinding action for the management of chronic wounds. Wound Care Canada 2012; 10(3):20-22

168 Bruce Z. Using Cutimed Sorbact hydroactive on chronic infected wounds. Wounds UK 2012; $8(1): 119-129$

169 Johansson A, Ljungh $\AA$, Apelqvist J. Open study on the topical treatment of interdigital fungal infections in diabetic patients. J Wound Care 2009; 18(11):470-473. https://doi.org/10.12968/jowc.2009.18.11.44988

170 World Health Organization. Global priority list of antibiotic-resistant bacteria to guide research, discovery, and development of new antibiotics. 2017. https://tinyurl.com/w2w6b6kd (accessed 9 December 2020) 
Fig 1. A leg ulcer infected with Pseudomonas aeruginosa that produces green pigmentation (image supplied by Medetec Ltd, copyright Medetec http://www.medetec.co.uk)
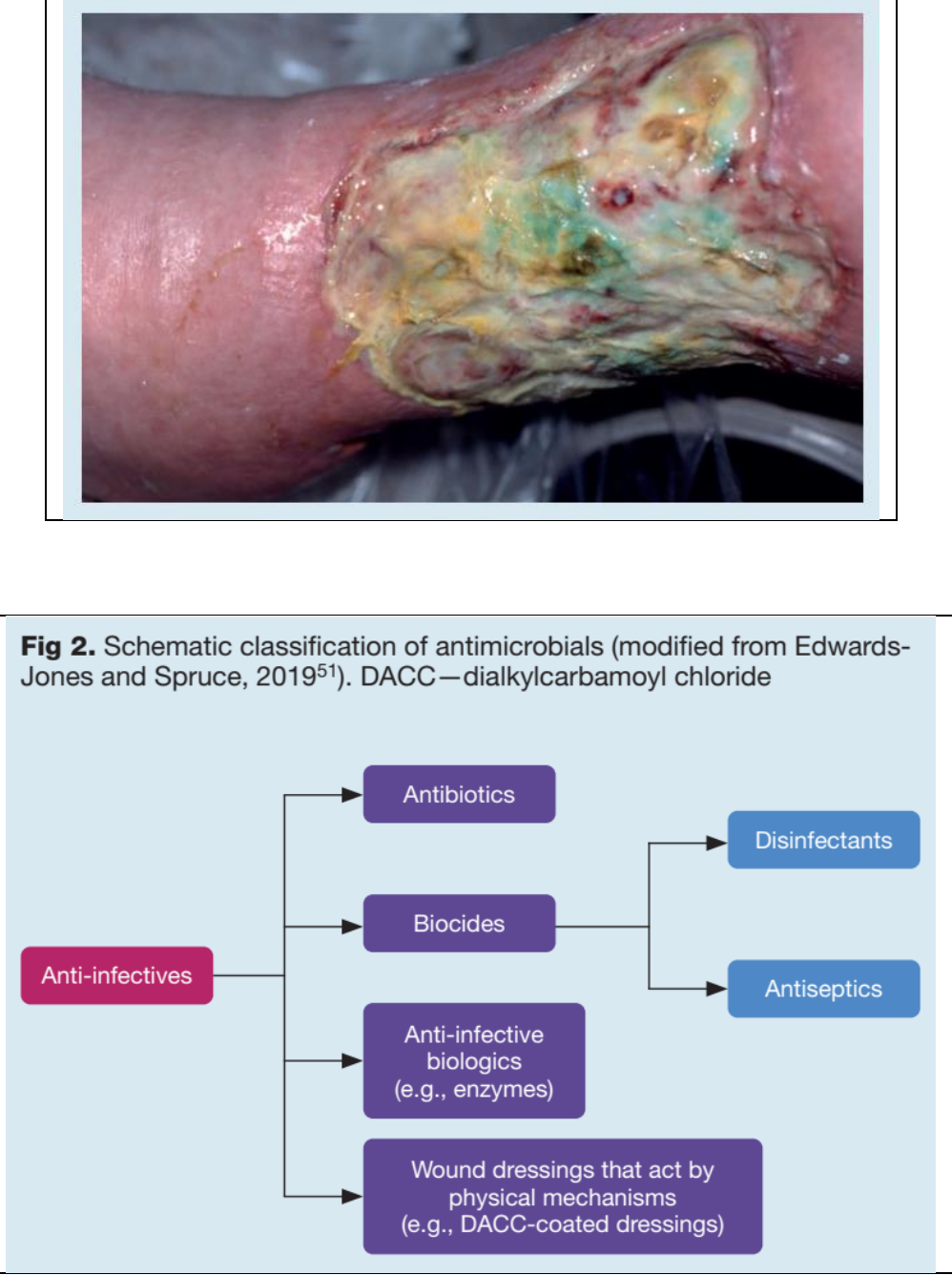
Fig 3. Dialkylcarbamoyl chloride (DACC)-coated dressing incubated with a mixture of microorganisms: Staphylococcus aureus (yellow), Pseudomonas aeruginosa (or Enterococcus faecalis (blue)), Klebsiella spp (green) and Candida albicans (orange). Note that microorganisms bind both to each other and to the dressing material. (Colourised scanning electron microscopy image to aid in distinguishing microorganisms) $)^{39,146}$

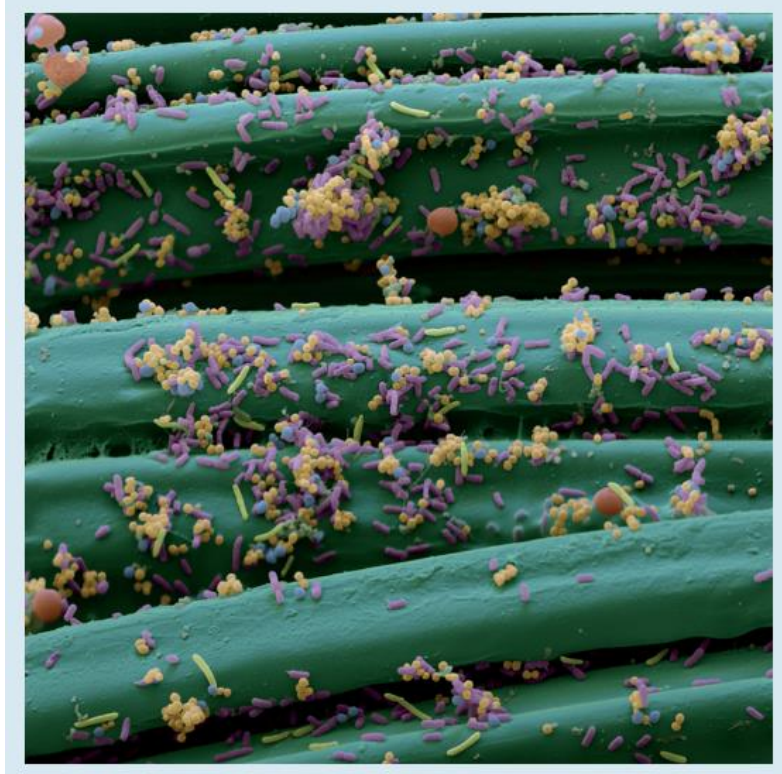

\begin{tabular}{|c|c|c|}
\hline Study & Microorganisms & Main Results \\
\hline $\begin{array}{l}\text { Wadström et al., } \\
1985^{148}\end{array}$ & Staphylococcus aureus & $\begin{array}{l}\text { In a porcine infected wound model, hydrophobic dressing eliminated infection } \\
\text { and enabled wound healing; infection remained with non-hydrophobic dressings }\end{array}$ \\
\hline $\begin{array}{l}\text { Bowler et al., } \\
1999^{149}\end{array}$ & $\begin{array}{l}\text { Staphylococcus aureus } \\
\text { Pseudomonas aeruginosa }\end{array}$ & $\begin{array}{l}\text { DACC-coated dressing absorbed and retained test microorganisms in a } \\
\text { laboratory test system and performed better than calcium alginate dressing }\end{array}$ \\
\hline $\begin{array}{l}\text { Ljungh et al., } \\
2006^{39}\end{array}$ & $\begin{array}{l}\text { Staphylococcus aureus } \\
\text { Pseudomonas aeruginosa } \\
\text { Enterococcus faecalis } \\
\text { Bacteroides fragilis } \\
\text { Fusobacterium nucleatum } \\
\text { Candida albicans }\end{array}$ & $\begin{array}{l}\text { Significant levels of binding to DACC-coated dressing for all microorganisms } \\
\text { tested; binding was observed after } 10 \text { minutes and peaked at two hours; reducing } \\
\text { hydrophobicity of microorganisms led to hydrophobic dressings being less } \\
\text { effective }\end{array}$ \\
\hline $\begin{array}{l}\text { Brackman et al., } \\
2013^{150}\end{array}$ & $\begin{array}{l}\text { Staphylococcus aureus } \\
\text { Staphylococcus epidermidis }\end{array}$ & $\begin{array}{l}\text { DACC-coated dressing bound Staphylococcus aureus suspension culture before } \\
\text { biofilm formation in a laboratory test; DACC-coated dressing was able to } \\
\text { significantly prevent biofilm formation in biofilms grown in an in vitro hard-to-heal } \\
\text { wound model }\end{array}$ \\
\hline $\begin{array}{l}\text { Geroult et al., } \\
2014^{151}\end{array}$ & Mycobacterium ulcerans & $\begin{array}{l}\text { Microorganism showed significantly higher binding to DACC-coated dressings } \\
\text { compared with the control dressing }\end{array}$ \\
\hline $\begin{array}{l}\text { Ronner et al., } \\
2014^{42}\end{array}$ & $\begin{array}{l}\text { Staphylococcus aureus } \\
\text { (including MRSA) }\end{array}$ & $\begin{array}{l}\text { All Staphylococcus aureus strains bound equally well to DACC-coated dressings } \\
\text { in laboratory studies, regardless of microorganism antibiotic sensitivity }\end{array}$ \\
\hline $\begin{array}{l}\text { Cooper and } \\
\text { Jenkins, 2016 }\end{array}$ & $\begin{array}{l}\text { MRSA } \\
\text { Pseudomonas aeruginosa }\end{array}$ & $\begin{array}{l}\text { DACC-coated dressing effectively binds both MRSA and Pseudomonas } \\
\text { aeruginosa biofilms in a laboratory test; Pseudomonas aeruginosa had a higher } \\
\text { affinity for the dressing than MRSA }\end{array}$ \\
\hline
\end{tabular}




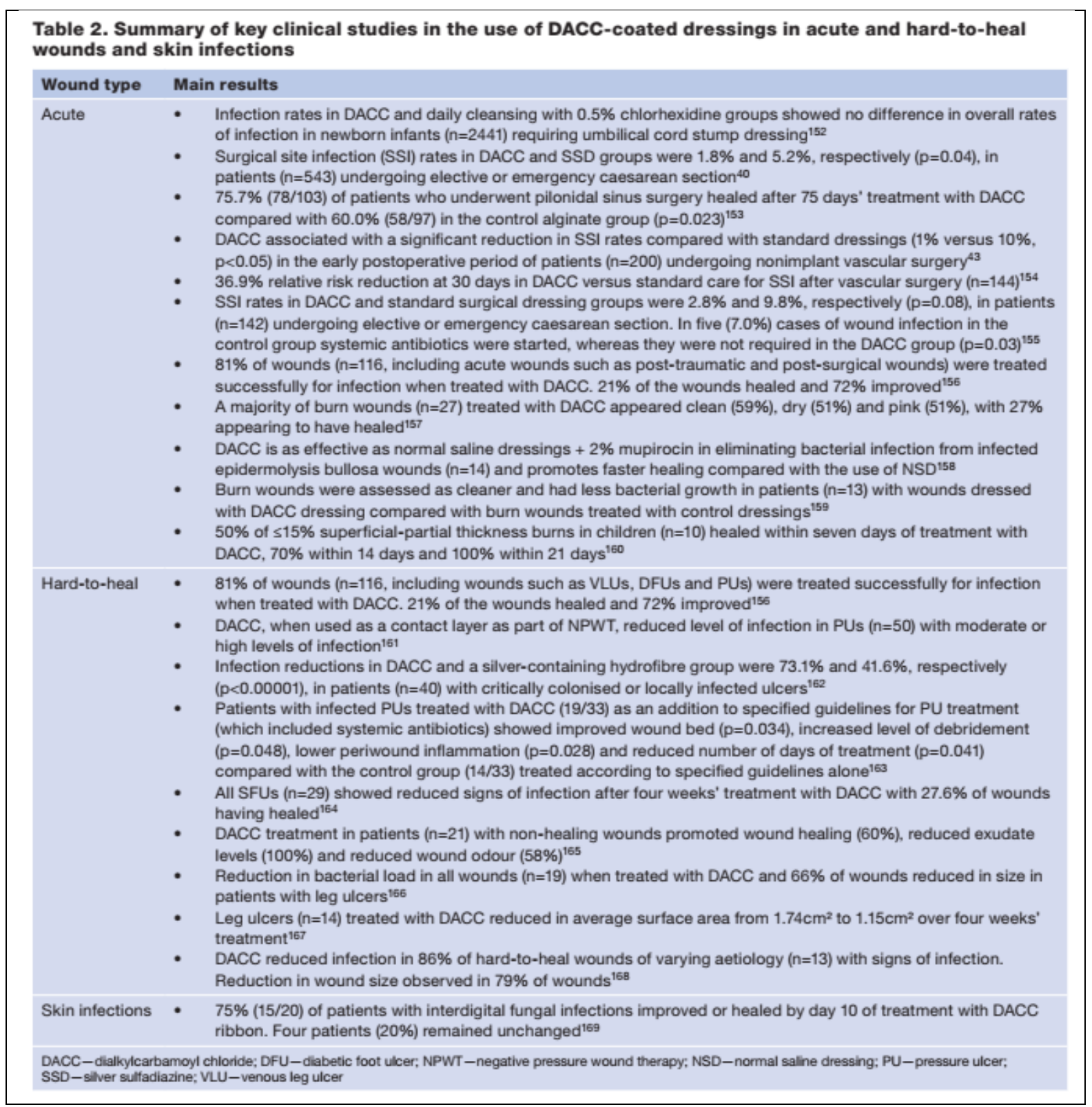


Table 3. World Health Organization priority antibiotic-resistant pathogens ${ }^{170}$

\begin{tabular}{|ll|}
\hline Priority & Pathogen \\
\hline Critical & $\begin{array}{l}\text { Acinetobacter baumannii, carbapenem-resistant } \\
\text { Pseudomonas aeruginosa, carbapenem-resistant } \\
\text { Enterobacteriaceae, carbapenem-resistant, ESBL-producing }\end{array}$ \\
\hline High & $\begin{array}{l}\text { Enterococcus faecium, vancomycin-resistant } \\
\text { Staphylococcus aureus, meticillin-resistant, vancomycin-intermediate, } \\
\text { and resistant } \\
\text { Helicobacter pylori, clarithromycin-resistant } \\
\text { Campylobacter, fluoroquinolone-resistant } \\
\text { Salmonellae, fluoroquinolone-resistant } \\
\text { Neisseria gonorrhoeae, cephalosporin-resistant, fluoroquinolone- } \\
\text { resistant }\end{array}$ \\
\hline Medium & $\begin{array}{l}\text { Streptococcus pneumoniae, penicillin-non-susceptible } \\
\text { Haemophilus influenzae, ampicillin-resistant } \\
\text { Shigella, fluoroquinolone-resistant }\end{array}$ \\
\hline ESBL-extended spectrum beta-lactamases
\end{tabular}

\section{Box 1: Actions for antimicrobial stewardship}

Avoid prescribing antimicrobials when they are not indicated

Prescribe an appropriate regimen when antimicrobial therapy is indicated

Prescribe antimicrobial therapy for the correct duration, at an optimal dose and via the most appropriate route

Use an agent that has the least risk of adverse events for the patient

Adapted from Dryden et al., $2011^{147}$ 